\title{
MAKALAH \\ KOMUNIKASI BISNIS \\ UPAYA UNTUK MENINGKATKAN EFEKTIFITAS KOMUNIKASI BISNIS
}

Diajukan untuk memenuhi tugas Mata Kuliah Komunikasi Bisnis

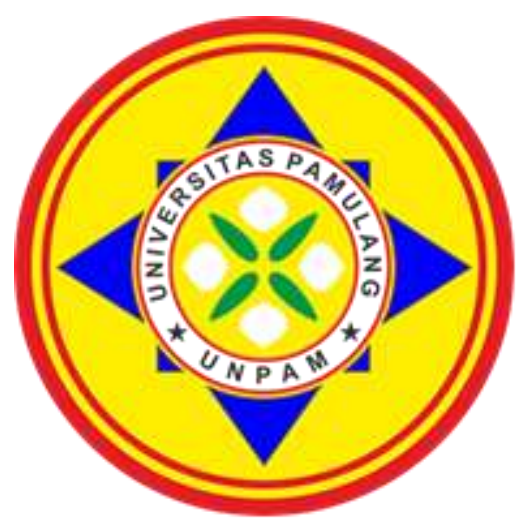

Disusun Oleh :

1. Ade Hayati Nufus

(171010508687)

2. Astria Nur Elita

(171010550047)

3. Ahmad Setiawan

(171010550066)

4. Iskak

(171010550052)

5. Jaenudin

(171010550019)

6. Nirmala Hidayah

(171010550974)

7. Rendy Prasetya

(171010502063)

8. Selvy Sendari

(171010551256)

\section{PROGRAM STUDI MANAJEMEN S-1}

FAKULTAS EKONOMI

UNIVERSITAS PAMULANG

TANGERANG SELATAN

2021 


\section{KATA PENGANTAR}

Puji dan syukur Alhamdulillah kehadirat Allah SWT yang telah melimpahkan segala rahmat dan karunia-Nya, sehingga penulis dapat menyelesaikan sehingga kami dapat menyelesaikan makalah tentang "Upaya Untuk Meningkatkan Efektifitas

\section{Komunikasi Bisnis"}

Makalah ini telah kami susun dengan maksimal dan mendapatkan bantuan dari berbagai pihak sehingga dapat memperlancar pembuatan makalah ini. Untuk itu kami menyampaikan banyak terima kasih kepada semua pihak yang telah berkontribusi dalam pembuatan makalah ini.

Dengan segala keterbatasan, penulis menyadari pula bahwa makalah ini takkan terwujud tanpa bantuan, bimbingan, dan dorongan dari berbagai pihak. Untuk itu, dengan segala kerendahan hati, penulis menyampaikan ucapan terima kasih kepada:

1. Dr. (H.C), Drs. H. Darsono, selaku Ketua Yayasan Sasmita Jaya.

2. Dr. E. Nurzaman, AM., M.M., M.Si., selaku Rektor Universitas Pamulang.

3. Dr. (c) Ubaid Al Faruq, S, Pd., M. Pd, selaku Wakil Rektor I Universitas Pamulang.

4. Dr. Subarto, M. Pd, selaku Wakil Rektor II Universitas Pamulang

5. Dr. M. Wildan, S.S., M.A., Selaku Wakil Rektor III Universitas Pamulang

6. Dr. RR. Dewi Anggraeni, S.H., M.H., selaku Wakil Rektor IV Universitas Pamulang. 
7. H. Endang Ruhiyat, S.E., M.M., C.S.R.A., C.M.A, selaku Dekan Fakultas Ekonomi dan Bisnis Universitas Pamulang

8. Dr. Kasmad, S.E., M.M., selaku Ketua Program Studi Manajemen S-1 Universitas Pamulang.

9. Ibu Selvy Dwi Widyanti, M.M., selaku Dosen kami pada Mata Kuliah Komunikasi Bisnis di Universitas Pamulang.

10. Bapak dan Ibu Dosen yang tidak bisa penulis sebutkan satu persatu, yang telah dengan keikhlasan, ketulusan dan dedikasi yang tinggi mengajarkan segenap kemampuan akademiknya kepada penulis.

11. Semua pihak yang tidak dapat penulis sebutkan satu persatu yang telah memberikan segala kebaikan dan bantuannya dalam penulisan ini.

Penulis memahami Makalah ini masih jauh dari sempurna. Karena itu, kritik dan saran akan senantiasa penulis terima dengan senang hati. Semoga Allah SWT membalas kebaikan dan selalu mencurahkan hidayah serta taufik-Nya, Amin Ya Robbal alamin.

Pamulang Selatan, November 2021

Penyusun

Kelompok 4 


\section{DAFTAR ISI}

KATA PENGANTAR................................................................................. ii

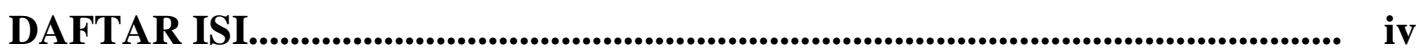

\section{BAB I PENDAHULUAN}

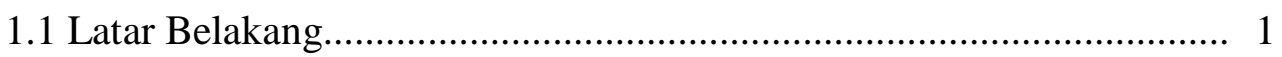

1.2 Identifikasi Masalah....................................................................... 2

1.3 Pembatasan Masalah............................................................................. 3

1.4 Perumusan Masalah............................................... 3

1.5 Tujuan........................................................... 4

1.6 Kegunaan........................................................ 4

\section{BAB II PEMBAHASAN}

2.1 Pengertian Komunikasi Bisnis......................................................... 6

2.2 Pentingnya Kemampuan Komunikasi Bisnis......................................... 7

2.3 Efektifitas Komunikasi Bisnis................................................ 10

2.4 Strategi Komunikasi dalam Mencapai Efektifitas

Komunikasi Bisnis.................................................................... 12

2.5 Pendapat Kelompok Tentang Upaya untuk Meningkatkan

Efektifitas Komunikasi Bisnis................................... 14

\section{BAB III PENUTUP}

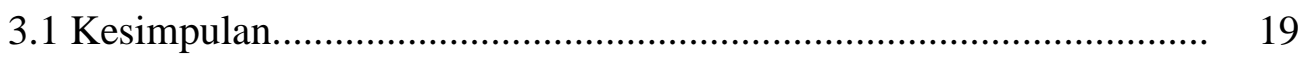

DAFTAR PUSTAKA.................................................................................................... 20 


\section{BAB I \\ PENDAHULUAN}

\subsection{Latar Belakang}

Komunikasi adalah suatu proses penyampaian dan penerimaan pesan atau informasi diantara dua orang atau lebih dengan harapan terjadinya pengaruh yang positif atau menimbulkan efek tertentu yang diharapkan. Komunikasi adalah persepsi dan apresiasi.

Memasuki millenium baru, dunia usaha banyak menghadapi masalah kompleks. Bukan saja karena cakupan bisnisnya yang semakin beragam, melainkan juga karena skala bisnis sudah menjadi problem yang sangat luas. Sejumlah ahli mengatakan bisnis sudah menjadi masalah global. Mengapa sampai demikian?

1. Pertama, karena semakin pesatnya kemajuan di bidang sains dan teknologi, sehingga merangsang terciptanya sistem dan proses produksi yang efisien. Produksi barang dan jasa sudah melampaui batas kebutuhan pasar dalam negeri, sehingga perlu di ekspor.

2. Kedua, karena teknologi telah mempercepat pembangunan sarana dan prasarana transportasi, sehingga mobilitas sosial menjadi semakin cepat dan tinggi.

3. Ketiga, bersamaan dengan itu, kemajuan di bidang transformasi informasi komunikasi juga berlangsung sangat pesat, sehingga informasi tentang keadaan tertentu dapat disampaikan tanpa tergantung pada jarak geografis. Bukan itu saja, kemajuan di bidang komunikasi (media massa) telah mempengaruhi pola-pola bisnis antar manusia. 
Fenomena inilah yang menyadarkan banyak orang betapa pentingnya memahami gejala komunikasi dalam rangka memahami gejala bisnis.

\subsection{Identifikasi Masalah}

Jika kita melihat bisnis dan komunikasi sebagai sama-sama suatu proses sosial, kita akan sampai pada kesimpulan bahwa komunikasi adalah bisnis dan, sebaliknya, bisnis adalah komunikasi. Artinya, pada tingkatan gejala [fenomena], antara komunikasi dan bisnis merupakan gejala yang terintegrasi. Tidak bisa dipisahpisahkan.

Bisnis dan komunikasi sama-sama memulai kegiatannya dengan melakukan proses produksi. Lebih jelasnya bisa dijelaskan sebagai berikut :

1. Dalam komunikasi, yang diproduksi dinamakan informasi; sedangkan dalam bisnis, yang diproduksi adalah barang dan jasa. Dalam konteks tertentu, informasi juga termasuk barang dan jasa. Misalnya : informasi lewat surat kabar, majalah, televisi, dll.

2. Kemudian, bisnis dan komunikasi menyampaikan produk tsb kepada pihak lain. Dalam komunikasi, pihak lain bisa disebut communicator, audience, destination, dst. Sementara dalam kegiatan bisnis pihak lain sering disebut konsumen, klien, buyer, dst.

3. Komunikasi dan bisnis sama-sama menimbulkan reaksi tertentu dan mempunyai hambatan-hambatan yang spesifik. 


\subsection{Pembatasan Masalah}

Dengan cara berpikir di atas, kita akan berusaha menjelajahi kajian-kajian yang relevan tentang hubungan bisnis dengan komunikasi. Ada tiga kajian yang bisa kita telaah :

1. Kajian tentang kegiatan bisnis dari perspektif komunikasi. Bagaimana sudut pandangan komunikasi menerangkan gejala bisnis.

2. Kajian tentang kegiatan komunikasi dari perspektif bisnis. Bagaimana sudut pandang bisnis dalam menerangkan kegiatan komunikasi. Atau, secara sederhana, komunikasi sebagai bisnis.

3. Kajian tentang faktor-faktor eksternal dari keduanya yang turut terlibat dalam proses komunikasi maupun bisnis.

\subsection{Perumusan Masalah}

1. Bagaimana cara membangun komunikasi yang baik dalam berbisnis?

2. Bagaimana proses komunikasi bisnis dalam perusahaan?

3. Pentingkah memiliki kemampuan komunikasi bisnis?

4. Apakah kendala dalam membangun komunikasi bisnis yang efektif?

5. Strategi apa yang dilakukan untuk mencapai komunikasi bisnis yang efektif agar dapat melewati kendala/hambatan dalam berkomunikasi? 


\subsection{Tujuan}

1. Mengetahui cara membangun komunikasi yang baik dalam berbisnis.

2. Mengetahui proses komunikasi bisnis.

3. Mengetahui strategi atau upaya untuk meningkatkan efektivitas komunikasi bisnis

\subsection{Kegunaan}

Komunikasi merupakan aktivitas dasar manusia. Dengan berkomunikasi, manusia dapat saling berhubungan satu sama lain baik dalam kehidupan sehari-hari di rumah tangga, di tempat pekerjaan, di pasar, dalam masyarakat atau di mana saja manusia berada. Tidak ada manusia yang tidak akan terlibat dalam komunikasi.

Pentingnya komunikasi bagi manusia tidaklah dapat dipungkiri begitu juga halnya bagi suatu organisasi. Dengan adanya komunikasi yang baik suatu organisasi dapat berjalan dengan lancar dan berhasil dan begitu pula sebaliknya, kurangnya atau tidak adanya komunikasi organisasi dapat macet dan berantakan. Misalnya bila dalam suatu sekolah kepala sekolah tidak memberi informasi kepada guru-guru mengenai kapan sekolah dimulai sesudah libur semester dan apa bidang studi yang harus diajarkan oleh masing-masing guru, maka besar kemungkinannya guru tidak datang mengajar. Akibatnya, murid-murid tidak belajar. Hal ini menjadikan sekolah tidak berfungsi sebagaimana mestinya.

Dari contoh itu kelihatan, bahwa dengan kelupaan memberi informasi saja sudah memberikan efek yang lebih besar bagi sekolah. Karena pentingnya komunikasi dalam organisasi maka perlu menjadi perhatian pengelola agar dapat membantu dalam 
pelaksanaan tugasnya. Komunikasi yang efektif adalah penting bagi semua organisasi. Oleh karena itu, para pemimpin organisasi dan para komunikator dalam organisasi perlu memahami dan menyempurnakan kemampuan komunikasi mereka (Kohler, 1981). 


\section{BAB II \\ PEMBAHASAN}

\subsection{Pengertian Komunikasi Bisnis}

Komunikasi adalah sesuatu hal dasar yang selalu dibutuhkan dan dilakukan oleh setiap insan manusia, karena berkomunikasi merupakan dasar interaksi antar manusia untuk memperoleh kesepakatan dan kesepahaman yang dibangun untuk mencapai suatu tujuan yang maksimal diantara kedua nya. Untuk mencapai usaha dalam berkomunikasi secara efektif, maka sebaiknya kita harus mengetahui sejumlah pemahaman dan persoalan yang terjadi dalam proses berkomunikasi itu sendiri.

Komunikasi bisnis adalah setiap komunikasi yang digunakan untuk membangun partnerships, sumber daya intelektual, untuk mempromosikan satu gagasan, suatu produk, servis, atau suatu organisasi, dengan sasaran untuk menciptakan nilai bagi bisnis yang dijalankan. Komunikasi Bisnis meliputi pengetahuan yang menyeluruh dari sisi internal dan eksternal bisnis tersebut. Komunikasi yang internal termasuk komunikasi visi (perseroan/perusahaan), strategi, rencana-rencana, kultur/budaya perusahaan, nilai-nilai dan prinsip dasar yang terdapat di perusahaan, motivasi karyawan, serta gagasan-gagasan, dll. Komunikasi eksternal termasuk merek, pemasaran, iklan, hubungan pelanggan, humas, hubungan-hubungan media, negosiasinegosiasi bisnis, dll. Bagaimanapun bentuknya, semua hal tersebut memiliki tujuan yang sama, yaitu menciptakan suatu nilai bisnis (create business value). 
Komunikasi bisnis adalah proses pertukaran pesan atau informasi untuk mencapai efektivitas dan efisiensi produk kerja di dalam struktur dan sistem organisasi. Dalam kegiatan komunikasi bisnis, pesan hendaknya tidak hanya sekedar informatif tetapi juga haruslah "Persuasif" agar pihak lain bersedia menerima suatu paham atau keyakinan atau melakukan suatu perbuatan atau kegiatan.

\subsection{Pentingnya Kemampuan Komunikasi Bisnis}

Tantangan seorang manajer di masa depan relatif akan semakin sulit, yang menuntut kemampuan untuk mengkomunikasikan ide gagasan dan tujuan dalam lingkungan organisasinya serta bagaimana menyampaikan produk atau jasa yang dimilikinya kepada pelanggan. Di sisi lain, proses manajemen, adalah suatu aktivitas komunikasi. Terdapat 5 kendala yang mungkin muncul saat manajer mengkomunikasikan bisnis organisasinya, yaitu :

1. Struktur komunikasi yang buruk

Struktur komunikasi adalah faktor esensial, yang menentukan baik-buruknya komunikasi bisnis. Tidak penting apakah audiencenya hanya satu orang atau ribuan orang dan sekalipun di tengah bisingnya lingkungan bisnis dan pemasaran, pesan yang disampaikan haruslah terdengar dan dimengerti. Struktur komunikasi yang baik, mengikuti pola :
a. Pembukaan
b. Isi
c. Penutup 
Tidak menjadi masalah, apakah pesan itu penting atau impresif. Namun apabila disampaikannya tanpa "sentuhan yang kuat", hasilnya tidak akan dapat menyakinkan orang lain sesuai harapan. Disamping itu, meskipun telah dilakukan "sentuhan " yang sudah tepat ternyata seringkali juga masih memerlukan waktu untuk mendapatkan respons. Dengan demikian, pesan yang kuat, tidak boleh seperti lawakan yang tidak lucu. Pesan yang disampaikan haruslah 'menyentuh' secara kuat dan telak, tidak sekedar mengelus-elus atau mengingatkan.

\section{Penggunaan media yang salah}

Perlu untuk mempertimbangkan siapa, dari kalangan atau status sosial mana dan karakteristik unik lainnya dari sasaran yang kita tuju, sehingga kita dapat memilih media yang tepat. Jika pesan yang disampaikan sangat kompleks, berikanlah ruang agar audience kita dapat mencerna pesan tersebut secara lebih leluasa, sesuai kecepatan mereka.

\section{Pesan yang campur aduk}

Pesan yang campur aduk, hanya akan menimbulkan kebingungan atau bahkan cemoohan dari audience. Seperti, larangan untuk memberikan hadiah kepada klien, tetapi pada saat yang sama memberikan pengecualian untuk klien-klien baru atau pelanggan VIP yang berpotensi besar pada bisnis perusahaan. Sementara, kriteria dari klien potensial atau pelanggan VIP tersebut tidak dirinci secara jelas.

\section{Salah Audience}

Topik yang dipilih hendaknya relevan dan sesuai dengan ekspektasi audience. Sebagai contoh, misalnya dalam event pertemuan antara wakil dari Pemerintah dan 
Pengusaha, namun dalam presentasi disajikan tentang analisis situasi politik dan pemerintahan, sedangkan para pengusaha, sebenarnya lebih mengharapkan penjelasan bagaimana tindakan atau langkah-langkah konkrit yang diambil pemerintah untuk menciptakan iklim usaha yang kondusif.

\section{Lingkungan yang mengganggu}

Lingkungan yang mengganggu jelas merupakan kendala dalam komunikasi, sehingga pesan yang disampaikan tidak dapat diterima / didengar secara optimal. Seperti Suara penyaji yang tidak cukup terdengar oleh Audience, Suara keras dari luar ruangan, (seperti raungan sirine ambulan atau suara lalu lintas yang padat ), Bunyi handphone dari kantong audience, Interupsi, Sesi bicara yang menegangkan, dsb.

Oleh karena itu, perlunya pemilihan tempat yang tepat serta upaya agar audience fokus dengan pesan yang disampaikan.

Kendala komunikasi bisnis dapat bermacam-macam, namun dengan kehatihatian serta kecermatan, sebagian kendala tersebut akan dapat diatasi. Presentasi yang disampaikan akan lebih bermakna dengan kendala yang diminimalisir, sehingga pesan yang disampaikan dapat memberikan efek yang diharapkan.

Seiring dengan perkembangan teknologi dan sistem informasi, komunikasi berkembang menjadi suatu bisnis tersendiri. Perkembangan sistem informasi dan teknologi mempercepat proses Globalisasi, sehingga proses komunikasi terjadi setiap saat tanpa berhenti dan berlangsung pada saat yang hampir bersamaan di seluruh belahan dunia. Informasi dengan mudah dan cepat menyebar, bahkan nyaris tanpa penghalang apapun. 
Perkembangan teknologi yang semakin pesat, memungkinkan orang untuk berkomunikasi melalui berbagai macam media. Tantangan ke depan, bukan saja sekedar menjual produk \& jasa perusahaan, tetapi bagaimana menyampaikan pesan bahwa produk atau jasa yang ditawarkan dapat memberikan manfaat kepada banyak orang dari berbagai ragam budaya, latar belakang, dan sebagainya. Proses penyampaian pesan atau informasi tersebut, dapat dilakukan secara satu arah, seperti melalui media elektronik atau media cetak juga dapat dilakukan secara dua arah (interaktif) melalui jaringan internet.

\subsection{Efektivitas Komunikasi Bisnis}

Efektivitas komunikasi bisnis, seperti halnya jenis komunikasi lainnya ditentukan beberapa hal :

1. Persepsi. Komunikator harus dapat memprediksi apakah message yang disampaikan dapat diterima komunikan.

2. Ketepatan. Komunikan atau audience memiliki kerangka pikir. Agar komunikasi yang dilakukan tepat sasaran, komunikator perlu mengeksperikan hal yang ingin disampaikan sesuai dengan kerangka pikir komunikan.

3. Kredibilitas. Dalam berkomunikasi, komunikator perlu memiliki suatu keyakinan bawah komunikan dapat dipercaya. Sebaliknya dia juga harus bisa mendapatkan kepercayaan dari komunikan.

4. Pengendalian. Dalam komunikasi, komunikan memberikan reaksi/umpan balik/feedback terhadap pesan yang disampaikan. Reaksi ini harus bisa diantisipasi 
sekaligus dikendalikan oleh komunikator sehingga tidak melenceng dari target komunikasi yang diharapkan.

5. Kecocokan. Komunikator yang baik selalu dapat menjaga hubungan persahabatan yang menyenangkan dengan komunikan.

VSementara Keterampilan meningkatkan efektivitas komunikasi bisa dilakukan dengan berbagai cara menyangkut komunikasi verbal non verbal, lisan maupun tulisan.

a. Reading

b. Listening

c. Speaking

d. Writing

Disadari ataupun tidak, setiap hari kita melakukan, paling tidak, satu dari keempat hal tersebut diatas dengan lingkungan kita. Seperti juga pernafasan, komunikasi sering dianggap sebagai suatu kejadian otomatis dan terjadi begitu saja, sehingga seringkali kita tidak memiliki kesadaran untuk melakukannya secara efektif.

Aktivitas komunikasi adalah aktivitas rutin serta otomatis dilakukan, sehingga kita tidak pernah mempelajarinya secara khusus, seperti bagaimana menulis ataupun membaca secara cepat dan efektif ataupun berbicara secara efektif serta menjadi pendengar yang baik.

Menurut "Stephen Covey: komunikasi merupakan keterampilan yang penting dalam hidup manusia". Unsur yang paling penting dalam berkomunikasi adalah bukan sekedar apa yang kita tulis atau yang kita katakan, tetapi karakter kita 
dan bagaimana kita menyampaikan pesan kepada penerima pesan. Penerima pesan tidak hanya sekedar mendengar kalimat yang disampaikan tetapi juga membaca dan menilai sikap kita. Jadi, syarat utama dalam komunikasi yang efektif adalah karakter kokoh yang dibangun dari fondasi etika serta integritas pribadi yang kuat.

Tidak peduli seberapa berbakatnya seseorang, betapapun unggulnya sebuah tim atau seberapapun kuatnya kasus hukum, keberhasilan tidak akan diperoleh tanpa penguasaan keterampilan komunikasi yang efektif. Keterampilan melakukan komunikasi yang efektif akan berperan besar dalam mendukung pencapaian tujuan dari seluruh aktivitas. Untuk dapat melakukan komunikasi yang efektif, maka kemampuan untuk mengirimkan pesan atau informasi yang baik, kemampuan untuk menjadi pendengar yang baik, serta keterampilan menggunakan berbagai media atau alat audio visual merupakan bagian yang sangat penting.

\subsection{Strategi Komunikasi dalam Mencapai Efektivitas Komunikasi Bisnis}

Dalam proses komunikasi semua pesan atau informasi yang dikirim akan diterima dengan berbagai perbedaan oleh penerima pesan/informasi, baik karena perbedaan latar belakang, persepsi, budaya maupun hal lainnya. Untuk itu, suatu pesan atau informasi yang disampaikan hendaknya memenuhi 7 syarat atau dikenal juga dengan $7 \mathrm{C}$, yaitu : 


\section{Completeness (Lengkap)}

Suatu pesan atau informasi dapat dikatakan lengkap, bila berisi semua materi yang diperlukan agar penerima pesan dapat memberikan tanggapan yang sesuai dengan harapan pengirim pesan

\section{Conciseness (Singkat)}

Suatu pesan dikatakan concise bila dapat mengutarakan gagasannya dalam jumlah kata sekecil mungkin (singkat, padat tetapi jelas) tanpa mengurangi makna, namun tetap menonjolkan gagasannya.

\section{Consideration (Pertimbangan)}

Penyampaian pesan, hendaknya menerapkan empati dengan mempertimbangkan dan mengutamakan penerima pesan.

\section{Concreteness (konkrit)}

Penyampaian pesan hendaknya disampaikan dengan bahasa yang gambling, pasti dan jelas.

\section{Clarity (Kejelasan)}

Pesan hendaknya disampaikan dengan bahasa yang mudah dimengerti dan mudah diinterpretasikan serta memiliki makna yang jelas.

\section{Courtessy (Kesopanan)}

Pesan disampaikan dengan gaya bahasa dan nada yang sopan, akan memupuk hubungan baik dalam komunikasi bisnis. 


\section{Correctness (ketelitian)}

Pesan hendaknya dibuat dengan teliti, dan menggunakan tata bahasa, tanda baca dan ejaan dengan benar (formal atau resmi).

\subsection{Pendapat Kelompok Tentang Upaya untuk Meningkatkan Efektifitas Komunikasi Bisnis}

Kemampuan komunikasi bisnis dalam upaya meningkatkan efektifitas sangat diperlukan, adapun upaya yang dapat dilakukan agar komunikasi bisnis dapat tercapai adalah sebagai berikut:

1. Berikan kesan bahwa anda antusias berbicara dengan mereka - Beri mereka kesan bahwa anda lebih suka berbicara dengan mereka dari pada orang lain di muka bumi ini. Ketika anda memberi mereka kesan bahwa anda sangat antusias berbicara dengan mereka dan bahwa anda peduli kepada mereka, anda membuat perasaan mereka lebih positif dan percaya diri. Mereka akan lebih terbuka kepada anda dan sangat mungkin memiliki percakapan yang mendalam dengan anda.

2. Ajukan pertanyaan tentang minat mereka - Ajukan pertanyaan terbuka yang akan membuat mereka berbicara tentang minat dan kehidupan mereka. Galilah sedetail mungkin sehingga akan membantu mereka memperoleh perspektif baru tentang diri mereka sendiri dan tujuan hidup mereka.

3. Beradaptasi dengan bahasa tubuh dan perasaan mereka - Rasakan bagaimana perasaan mereka pada saat ini dengan mengamati bahasa tubuh dan nada suara. 
Dari sudut pandang ini, anda dapat menyesuaikan kata-kata, bahasa tubuh, dan nada suara anda sehingga mereka akan merespon lebih positif.

\section{Tunjukkan rasa persetujuan: Katakan kepada mereka apa yang anda} kagumi tentang mereka dan mengapa - Salah satu cara terbaik untuk segera berhubungan dengan orang adalah dengan menjadi jujur dan memberitahu mereka mengapa anda menyukai atau mengagumi mereka. Jika menyatakan secara langsung dirasakan kurang tepat, cobalah dengan pernyataan tidak langsung. Kedua pendekatan tersebut bisa sama-sama efektif.

\section{Dengarkan dengan penuh perhatian semua yang mereka katakan - Jangan} terlalu berfokus pada apa yang akan Anda katakan selanjutnya selagi mereka berbicara. Sebaliknya, dengarkan setiap kata yang mereka katakan dan responlah serelevan mungkin. Hal ini menunjukkan bahwa anda benar-benar mendengarkan apa yang mereka katakan dan anda sepenuhnya terlibat di dalam suasana bersama dengan mereka. Juga pastikan untuk bertanya setiap kali ada sesuatu yang tidak mengerti pada hal-hal yang mereka katakan. Anda tentu saja ingin menghindari semua penyimpangan yang mungkin terjadi dalam komunikasi jika anda ingin mengembangkan hubungan yang sepenuhnya dengan orang tersebut.

6. Beri mereka kontak mata yang lama - kontak mata yang kuat mengkomunikasikan kepada orang lain bahwa anda tidak hanya terpikat oleh mereka dan apa yang mereka katakan tetapi juga menunjukkan bahwa anda dapat dipercaya. Ketika dilakukan dengan tidak berlebihan, mereka juga akan menganggap anda yakin pada diri anda sendiri karena kesediaan anda untuk 
bertemu mereka secara langsung. Akibatnya, orang secara alami akan lebih memperhatikan anda dan apa yang anda katakan.

7. Ungkapkan diri anda sebanyak mungkin - Salah satu cara terbaik untuk mendapatkan kepercayaan seseorang adalahdengan mengungkapkan diri seterbuka mungkin. Bercerita tentang kejadian yang menarik dari hidup anda atau hanya menggambarkan contoh lucu dari kehidupan normal sehari-hari. Ketika anda bercerita tentang diri anda, pastikan untuk tidak menyebutkan hal-hal yang menyimpang terlalu jauh dari minat mereka atau bahkan berlebihan. Anda dapat membiarkan mereka mengetahui lebih jauh tentang diri anda seiring berjalannya waktu.

8. Berikan kesan bahwa anda berdua berada di tim yang sama - Gunakan katakata seperti "kami, kita" untuk segera membangun sebuah ikatan. Bila anda menggunakan kata-kata tersebut, anda membuatnya tampak seperti anda dan mereka berada di tim yang sama, sementara orang lain berada di tim yang berbeda.

9. Berikan mereka senyuman terbaik anda - Ketika anda tersenyum pada orang, anda menyampaikan pesan bahwa anda menyukai mereka dan kehadiran mereka membawa anda kebahagiaan. Tersenyum pada mereka akan menyebabkan mereka sadar ingin tersenyum kembali pada anda yang secara langsung akan membangun hubungan antara anda berdua.

10. Menawarkan saran yang bermanfaat - Kenalkan tempat makan yang pernah anda kunjungi, film yang anda tonton, orang-orang baik yang mereka ingin temui, buku yang anda baca, peluang karir atau apa pun yang terpikirkan oleh anda. 
Jelaskan apa yang menarik dari orang-orang, tempat atau hal-hal tersebut. Jika anda memberi ide yang cukup menarik perhatian mereka, mereka akan mencari anda ketika mereka memerlukan seseorang untuk membantu membuat keputusan tentang apa yang harus dilakukan selanjutnya.

11. Beri mereka motivasi - Jika orang yang anda hadapi lebih muda atau dalam posisi yang lebih sulit dari anda, mereka mungkin ingin mendengar beberapa kata motivasi dari anda karena anda lebih berpengalaman atau anda tampaknya menjalani kehidupan dengan baik . Jika anda ingin memiliki hubungan yang sehat dengan orang tersebut, anda tentu saja tidak ingin tampak seperti anda memiliki semuanya sementara mereka tidak. Yakinkan mereka bahwa mereka dapat melampaui masalah dan keterbatasan mereka, sehingga mereka akan berharap menjadikan anda sebagai teman yang enak untuk diajak bicara.

\section{Tampil dengan tingkat energi yang sedikit lebih tinggi dibanding orang lain -}

Umumnya, orang ingin berada di sekitar orang-orang yang akan mengangkat mereka, bukannya membawa mereka ke bawah. Jika anda secara konsisten memiliki tingkat energi yang lebih rendah daripada orang lain, mereka secara alami akan menjauh dari Anda menuju seseorang yang lebih energik. Untuk mencegah hal ini terjadi, secara konsisten tunjukkan dengan suara dan bahasa tubuh anda bahwa anda memiliki tingkat energi yang sedikit lebih tinggi sehingga mereka akan merasa lebih bersemangat dan positif berada di sekitar Anda. Namun jangan juga anda terlalu berlebihan berenergik sehingga menyebabkan orang- 
orang tampak seperti tidak berdaya. Energi dan gairah yang tepat akan membangun antusiasme mereka.

\section{Sebut nama mereka dengan cara yang menyenangkan telinga mereka - nama} seseorang adalah salah satu kata yang memiliki emosional yang sangat kuat bagi mereka. Tapi hal itu belum tentu seberapa sering anda katakan nama seseorang, namun lebih pada bagaimana anda mengatakannya. Hal Ini dapat terbantu dengan cara anda berlatih mengatakan nama seseorang untuk satu atau dua menit sampai anda merasakan adanya emosional yang kuat. Ketika anda menyebutkan nama mereka lebih menyentuh dibanding orang lain yang mereka kenal, mereka akan menemukan bahwa anda lah yang paling berkesan.

14. Tawarkan untuk menjalani hubungan selangkah lebih maju - Ada beberapa hal yang dapat anda lakukan untuk memajukan persahabatan anda dengan seseorang: tawaran untuk makan dengan mereka, berbicara sambil minum kopi, melihat pertandingan olahraga, dll. Meskipun jika orang tersebut tidak menerima tawaran anda, mereka akan tetap tersanjung bahwa anda ingin mereka menjalani persahabatan ke tingkat yang lebih dalam. Di satu sisi, mereka akan memandang anda karena anda memiliki keberanian untuk membangun persahabatan bukan mengharapkan persahabatan yang instan. 


\section{BAB III KESIMPULAN}

\subsection{Kesimpulan}

Komunikasi bisnis adalah proses pertukaran pesan atau informasi untuk mencapai efektivitas dan efisiensi produk kerja di dalam struktur dan sistem organisasi. Dalam kegiatan komunikasi bisnis, pesan hendaknya tidak hanya sekedar informatif tetapi juga haruslah Persuasif, agar pihak lain bersedia menerima suatu paham atau keyakinan atau melakukan suatu perbuatan atau kegiatan.

Di era globalisasi ini, tantangan seorang manajer di masa depan relatif akan semakin sulit, karena dunia bisnis menghadapi lingkungan persaingan yang cenderung semakin ketat. Para manajer perlu membekali diri dengan keterampilan lintas budaya, berupa kemampuan berinteraksi dengan berbagai ragam budaya, gaya manajemen / bisnis bangsa lain, maupun kerjasama tim, baik intern maupun dalam suatu aliansi strategis dengan mitra bisnis. Disini peran komunikasi bisnis menjadi semakin sangat penting, yaitu kemampuan membaca, menafsirkan laporan dan informasi dari lingkungan. Disamping menyampaikan gagasan, baik lisan maupun tertulis secara sistematik.

Di era e-bisnis, Komunikasi berkembang menjadi suatu bisnis tersendiri. Perkembangan sistem informasi dan teknologi mempercepat proses Globalisasi dan memberikan peluang bagi dunia usaha di Indonesia untuk mengembangkan usahanya, melalui berbagai kesempatan menjalin relasi bisnis, pemasaran produk ataupun lainnya. 


\section{DAFTAR PUSTAKA}

http://komunikasidalambisnis.blogspot.com/

http://biangebook.blogspot.com/2009/04/ebook-bisnis-komunikasi-bisnis.html

http://www.akuinginsukses.com/14-teknik-komunikasi-yang-paling-efektifl 